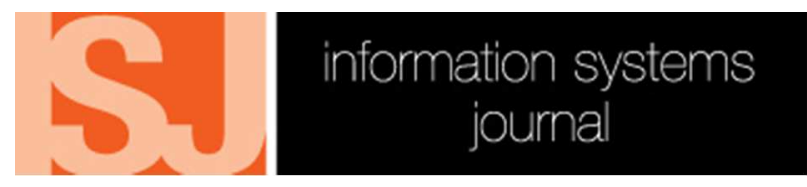

\title{
Entering the Field in Qualitative Field Research: A Rite of Passage into a Complex Practice World
}

\begin{tabular}{|c|l|}
\hline Journal: & Information Systems Journal \\
\hline Manuscript ID & ISJ-RE-1214.R2 \\
\hline Weywords: Manuscript type: & $\begin{array}{l}\text { Research Article } \\
\text { Entrance, Access, Qualitative Research Methods }\end{array}$ \\
\hline Abstract: & $\begin{array}{l}\text { The concept of 'the field' is significant in ethnographic research as well as } \\
\text { qualitative research methods more generally. However, how a field } \\
\text { researcher enters the field is usually taken for granted after gaining access } \\
\text { to the field. We suggest that entrance is a distinct phase of fieldwork that } \\
\text { differs from negotiating access. Entrance is not a trivial event; rather, it is } \\
\text { a rite of passage into a complex practice world and marks a critical field } \\
\text { moment. Drawing on our ethnography and insights from hermeneutics and } \\
\text { anthopology, we show that a practical understanding of the field } \\
\text { represents a fusion of horizons where a fieldworker is thrown. The concept } \\
\text { of thrownness highlights the fact that the fieldworkers' own historicity and } \\
\text { prejudices affect their entrance into the field; hence entrance into the field } \\
\text { orientates an ethnographer in the field and influences the entire period of } \\
\text { fieldwork that follows. Our theorizing is intended as a contribution towards } \\
\text { advancing the discussion of qualitative research methods. }\end{array}$ \\
\hline
\end{tabular}




\section{Entering the Field in Qualitative Field Research: A Rite of Passage into a Complex Practice World}

\section{Abstract}

The concept of 'the field' is significant in ethnographic research as well as qualitative research methods more generally. However, how a field researcher enters the field is usually taken for granted after gaining access to the field. We suggest that entrance is a distinct phase of fieldwork that differs from negotiating access. Entrance is not a trivial event; rather, it is a rite of passage into a complex practice world and marks a critical field moment. Drawing on our ethnography and insights from hermeneutics and anthropology, we show that a practical understanding of the field represents a fusion of horizons where a fieldworker is thrown. The concept of thrownness highlights the fact that the fieldworkers' own historicity and prejudices affect their entrance into the field; hence entrance into the field orientates an ethnographer in the field and influences the entire period of fieldwork that follows. Our theorizing is intended as a contribution towards advancing the discussion of qualitative research methods.

Keywords: fieldwork, entrance, access, ethnography, hermeneutics, interpretive field research, qualitative research methods 


\section{INTRODUCTION}

Ethnographic research in Information Systems (IS) is often used in interpretive and critical studies of social, organizational and technological phenomena (e.g., Lee and Myers, 2004; Bell et al., 2005; Jones, 2014; Oreglia and Srinivasan, 2016). It is an anthropological method with strong philosophical and theoretical foundations (Geertz, 1973, 2000). The ethnographic corpus in IS research contains significant contributions to methodology such as guidelines of field research (Klein and Myers, 1999), dramaturgical analysis of qualitative interviews (Myers and Newman, 2007), spatiality in the fieldwork (Dourish and Bell, 2007), confessional and reflexive techniques (Schultze, 2000a, b), and most recently a toolkit for design ethnography (Baskerville and Myers, 2015).

One of the essential features of any ethnographic study is fieldwork. An ethnographic field researcher, or simply a fieldworker, enters the field in order to learn about social and cultural practices and their meanings. In a sense, a fieldworker is like a child who learns by observing and participating in a new world (Van Maanen, 2011a, p. 75; 2011b, p. 220). After gaining the access to the field, an ethnographer attempts to develop "an intimate familiarity with the dilemmas, frustrations, routines, relationships, and risks that are part of everyday life" in order to understand the practice world of the participants (Myers, 1999, p. 5).

The concept of the field is significant not just in ethnographic research but in qualitative field research methods more generally. In qualitative research and ethnographic research in particular, how a qualitative researcher enters the field is usually taken for granted. In the literature entrance is often seen as synonymous with negotiating access to the field; that is, as an administrative issue. The focus of discussions of qualitative methods usually centres on later issues in the field concerning data collection or analyses (e.g., Nandhakumar and Jones, 1997, p. 117; Schultze, 2000b, pp. 92-3; cf. Myers, 2013, pp. 80ff, 139ff). Entering the field thus tends to be seen as a rather trivial event in the course of the fieldwork, the only issue being one of negotiating access to the research site. 
We propose that entrance into the field marks a critical field moment that affects the entire course of fieldwork that follows (Turner, 1997; Trigger et al., 2012, p. 514). Turner (1997) says that "critical moments" in the field are periods of significance, sense- and meaningmaking (for seminal ethnographic example see Geertz, 1973, pp. 413-416). For fieldworkers, a critical field moment is thus not a fixed temporal point that can simply be grasped instantaneously after securing access to the field. Rather fieldworkers need to be vulnerable to what is going on in the field practices in order to make sense of the critical field moments and, in so doing, enter the practice world of the field (Goffman, 1989). Entrance thus marks an important milepost in the fieldwork, and is just as important as access, acceptance ('living with' the participants), immersion ('living like' the participants), and exiting the field (Michailova et al., 2014; Van Maanen, 2011a; b, p. 2, 80). The entrance into the field orients the ethnographer in a new practice world (Geertz, 1973, pp. 10-28) and is in effect a rite of passage (Van Gennep, 1977), providing a deeper understanding of field practices. Turner $(1974,1997)$ says that fieldworkers need to develop new interpretations of rites of passage as critical field moments. To that end, we extend the traditional notion of rite of passage as one that applies to fieldworkers themselves and adopt an interpretation that requires ongoing engagement with practices.

In this paper, we provide a critical interpretive theorizing of a fieldworker's entrance into the field. We follow Heidegger (2008) and, in particular, his being-in-the-world analysis, to develop an engaged interpretation of entering the field. We understand a fieldworker's entrance into the field as being thrown into a world where one makes sense of it using one's historical position across space and time, amidst already existing structures, things and practices (Heidegger, 2011, p. 26; cf. Schatzki, 2006, p. 171; Van Maanen, 2011a). Thus, we acknowledge that we always already have a horizon of understanding before we enter the field. The concept of thrownness suggests that we interpret and understand the world from the horizon of our prior background practices and experience (Heidegger, 2008, p. 36ff; cf. 
Rabinow and Stavrianakis, 2013). Our horizon of understanding provides us with our spatiotemporal orientation in the field (cf. Geertz, 1973). Such horizons of understandings include, but are not limited to, our historicity, temporality, spatiality, everyday language and presuppositions of the phenomena (Gadamer, 1989). From these horizons we make sense of the various situations in the field that we find ourselves in. Accordingly, entrance can thus be examined and understood through an interplay of multiple horizons of understanding.

Our empirical evidence comes from an ethnographic field study at a reasonably large-scale information technology (IT) services organization in the Asia-Pacific region. We offer an interpretation of entrance into the field as a rite of passage into a practice world where an ethnographer is thrown (cf. Marcus, 2009, p. 12; Sluka and Robben, 2012, p. 17).

The structure of this paper is as follows. We first discuss the need for the theorization of entrance into the field. We then present some hermeneutic principles to lay the groundwork for our interpretation. Next, we discuss entrance into the field in terms of Heidegger's concept of thrownness. This is followed by a presentation of some empirical evidence from the field. The final section provides a critical discussion on the methodological implications for IS scholars and field researchers.

\section{INTERPRETING THE FIELD IN FIELDWORK}

The concept of 'the field' is central to qualitative inquiry, particularly ethnography and interpretive field research (Goffman, 1989; Jones, 2014; Klein and Myers, 1999; Van Maanen, 2011a; Ybema et al., 2009). However, what is the field? And, particularly, what does it mean to enter the field? Is the field simply a locality out there, waiting to be discovered? If that is the case, then entering the field is a rather trivial exercise; it is a mere stepping stone after gaining access to a physical, symbolic or virtual venue.

Organizational field researchers often see their physical entrance to a research site as entrance into a practice world (Jones, 2014, p. 116; Pole and Hillyard, 2016). That is, 
entrance is understood as a physical activity achieved by the virtue of negotiating access to the research site. The politics of negotiation and interpersonal challenges of gaining sustainable access to the field have already been discussed elsewhere (on complex access strategies see Van Maanen, 2011b, pp. 84ff; also Reeves, 2010). We acknowledge that gaining access is an important issue, and access needs to be maintained by developing relationships in the field and sustained during the course of the fieldwork (Harrington, 2003).

However, it is one thing to gain physical access to the field site, and another to enter the practice world, be accepted, and be there along with the participants, living with them in their everyday situations (Kunda, 2013). That is, before a field researcher attempts to immerse herself in the field practices, it is required to enter the practice world where she wants to be immersed. It is thus possible for a naïve field researcher, if all they are concerned about is access, to appear to the participants as a stranger trying to break in to their practice world, somewhat akin to being a "burglar-researcher" (Alvesson, 2009, p. 162). As Jones (2014) points out, while gaining access requires following the rules and norms of the research site, such administrative strategies are not always sufficient to enter the lives of people in the field. Jones uses Goffman (1989) to broaden distinction between getting in (access) and getting on (entrance, acceptance) to illustrate the difference between approaching the field and being in the field. We take this argument further and suggest that entrance marks a critical field moment whereby field researchers can gain rich local knowledge from the inside of the field (Geertz, 2000).

All field researchers begin their journey as strangers trying to make sense of a new unfamiliar world (Fine and Hallett, 2014; Kunda, 2013). But after gaining access, entrance is when a researcher's status changes from that of an outsider to being a member (albeit only temporarily) of the practice world (Moeran, 2009). We see entrance as a rite of passage into a practice world (cf. Clifford, 1983). One's entrance into the field marks a status changing event that is pivotal in forging a plausible ethnography. Entrance into the field orientates an 
ethnographer in the field and thus influences the entire period of fieldwork that follows (Harrington, 2003, p. 594; Schwartz-Shea and Yanow, 2009, pp. 65-6). In this perspective, entrance into the field is disclosed as a significant rite of passage from a theoretical as well as a practical point of view (cf. Turner, 1974, pp. 56ff). For instance, entrance can determine the field researchers' position within the circle of understanding in the field, where they fit, and where they find themselves in the existing everyday world of the participants (Geertz, 1973; Rabinow, 2007). Hence how one enters the field can influences the dynamics of the fieldwork and to a large extent determines what one is going to find out (Rabinow and Stavrianakis, 2013, pp. 31-46). The way a field researcher enters the field determines the way the fieldwork will be conducted; a problematic entrance might lead to problems of authenticity and plausibility of the research later on.

While access to the field is mostly an administrative or structural issue, entrance is an exercise in meaning- and sense-making in the field in which a fieldworker attempts to become part of a larger whole. Perhaps the significance of entrance can be further brought forth by understanding the field where one enters. The field is the home of the phenomena and, as Dreyfus (1991, p. 162) explicates, "we can only describe the phenomena as they show themselves and show how they fit with the rest of human existence." Here, the task of an ethnographer is argued to coherently document the field practices in order to tell a plausible account of how the field phenomena is entwined with practices through dialogical reasoning while preserving and disclosing multiple horizons of understandings (Clifford, 1988, p. 63). The entrance is thus an initial encounter with a complex practice world (Van Maanen, 2011a; cf. Heidegger, 2011, pp. 210ff) where the participants are already entwined in a nexus of historical practices (Schatzki, 2010). A field researcher encounters, lives through, and makes sense of this world by engaging in the everyday practices in the field (Anteby, 2013; cf. Goffman, 1989, p. 125). 
In order to achieve entrance, the field researcher needs to develop an intimate familiarity with the everyday affairs of the people (see Geertz, 1973, pp. 432ff). Such an enterprise calls for absorbing oneself in the field and involves skilful coping in everyday practices to reach the "epistemic core" of the field (Fine and Hallett, 2014, p. 191; cf. Dreyfus, 1991, pp. 60ff). In this way, gradually the fieldworker's comprehension of the field phenomena becomes automatic and her responses transparent in practice. While access is often a negotiated process, entrance is an engaged practice that is often achieved by being vulnerable and engaged with the field situations (Geertz, 1973, pp. 413-7; Goffman, 1989). Thus, insofar as a fieldworker steadily becomes one with the world of participants, the field practices slowly become intelligible; the field tends to become a familiar place rather than an alien world. A fieldworker finds her place in the field apropos a part belonging to a whole (Anteby, 2013; Rabinow, 2007). As this transparency is achieved in practice, the field becomes a world where one belongs, where everything makes sense simply by virtue of being there (Geertz, 2000, p. 69; cf. Van Maanen, 2011a). Being there, living with people in their everyday situations, is what gives the fieldwork its significance. We now further elaborate on the significance of the dialectical nature of being there, a part belonging to a whole, using the concept of the hermeneutic circle (for a related discussion in IS theory, see Klein and Myers, 1999, pp. 71ff; Cole and Avison, 2007, pp. 822ff).

\section{The Field as a Hermeneutic Circle}

While we acknowledge that there might be other points of departure to grasp entrance to the field (Gupta and Ferguson, 1997), we draw on insights from phenomenological hermeneutics to theorize entrance into the field, consistent with our critical interpretive lens (Heidegger, 2008; Geertz, 2000). We, first of all, problematize the concept of the field by mapping it to the hermeneutic circle insofar as it deals with the "dialectic between the understanding of the text as a whole and the interpretation of its parts, in which descriptions are guided by anticipated explanations" (Myers, 2004, p. 107). Using the hermeneutic circle to interpret the logic of 
everyday practices, we understand that we always already find ourselves in a practical situation where our meaning- and sense-making of a phenomenon pivots on our apposite prior experiences, pre-understandings and presuppositions (Gadamer, 1989, pp. 268ff; Heidegger, 2008, pp. 188ff). Thus, by being inside of practices we make sense of the world and the phenomena concerned.

Geertz (2000, pp. 5ff) applies the concept of the hermeneutic circle to fieldwork by discussing how fieldworkers develop a practical understanding of the field phenomena. For example, if we are studying a particular culture, in the field, the part (e.g., sacred symbol) can only be understood in the context of the whole (e.g., a culture, a belief system). Similarly, when a fieldworker accesses the field, he or she might not be aware of the whole context, and thus has to enter the practice world in order to try to grasp its practical logic (cf. Van Maanen, 2011a, p. 220).

In a sense, field researchers are also in a hermeneutic circle (cf. Schultze, 2000a, pp. 25ff) as they continually engage with many interpretations of their self-understanding and their understanding of the world viz. the field where they find themselves. Thus, acknowledging Geertz (2000), we can say all interpretations of the field need to begin by taking an engaged immersive view i.e., of being already absorbed in the practices of the field. As Dreyfus (1991, p. 4) succinctly points out, "one must always do hermeneutics from within a hermeneutic circle." Entrance, too, can only be partially understood by a conceptually detached theorizing; rather, it requires one to be practically engaged in the field. We now make the logic of the entrance into field explicit by discussing the structure of understanding in a hermeneutic circle (the field). 


\section{The Structure of Understanding in a Hermeneutic Circle}

The hermeneutic circle can be seen as a dialectic of many horizons of understanding. In this dialectic, Heidegger (2008, pp. 191ff) points to a trinity of minute horizons within every interpretation which he refers to as fore-structure that consists of,

i) fore-having (our taken for granted background);

ii) fore-sight (our assumptions concerning the interpretations); and,

iii) fore-conception (our expectations; something we already grasp).

The hermeneutic circle thus spells out the significance and intricacies of our presuppositions. While fore-having can be understood as what the fieldworker takes for granted about the field site, fore-sight is the horizon from where one observes and participates in the site. From the perspective of one horizon, one observes the other, taken together it is our fore-conception which enables us to make sense of the phenomena in the field. Thus our background, our historicity, plays a crucial role in our everyday sense-making. In this way, before one develops a practical understanding of the field practices, it is essential to grasp the field phenomena appropriately. Heidegger (2008, p. 195) puts emphasis on one's entrance into the hermeneutic circle as follows:

What is decisive is not to get out of the [hermeneutic] circle but to come into it in the right way.... To be sure, we genuinely take hold of this possibility only when, in our interpretation, we have understood that our first, last, and constant task is never to allow our fore-having, foresight, and fore-conception to be presented to us by fancies and popular conceptions, but rather to make the scientific theme secure by working out these fore-structures in terms of the things themselves.

Hence, Heidegger stresses, all understandings are connected in a series of fore-structures including one's historicity - that cannot be eliminated. He says that we cannot truly set aside our prior knowledge before interpreting a phenomenon. If we apply this to fieldwork, this means that the fieldworker needs to become as aware as possible of these fore-structures 
and take account of these interpretive influences in their entrance to the field. Being aware of fore-having, fore-sight and fore-conception serves as the foundation for understanding the field phenomena. We can say that the authenticity of the interpretation of any observation hinges on a fieldworker becoming aware of and transparently engaging with the phenomenon in the field; a critical understanding of fore-structure enables a fieldworker to go deep into participants' practice worlds.

Dreyfus (1991, p. 199) advances the discussion and explicates the significance of the forestructure in an interpretation and redirects our attention to the circular relationship caused by our expectations (fore-conception) when making sense of a phenomenon. An interpretation occurs against a backdrop of assumptions in which the latter itself is conditioned upon the former through understanding (Figure 1).

[insert Figure 1 about here]

The circular relationship as illustrated in Figure 1 problematizes our understandings of everyday situations in which we encounter the phenomena. For instance, we develop understanding by interpreting a situation, but our interpretation is based on our assumptions concerning the phenomenon. Thus, we cannot truly set aside our presuppositions; any new understanding is always mediated through our historicity (Geertz, 2000). Further, Gadamer (1989, pp. 271-3, 305) points out that our many horizons of understanding within the forestructure seamlessly work together or 'fuse' with each other. The field is a "fusion of horizons" in which an ethnographer utilizes various perspectives through their prior and historical knowledge, their horizons of understanding (Gadamer, 1989, p. 337; Boland and Tenkasi, 1995). We will now take this idea further by discussing the hermeneutic concept of prejudice within an interpretation. 


\section{The Role of Prejudice}

In critical hermeneutics, prejudice is not necessarily negative (as in say, racial prejudice). According to Gadamer (1989, pp. 269ff), prejudice is our prior awareness or understanding of something. Our prejudices, our likes and dislikes, are based on our previous experience and in a way sum up where we are coming from. In our fieldwork, we cannot just detach ourselves from our history and pretend we are a fly on the wall. Gadamer points out that without any prejudices (i.e., our pre-understanding) we cannot develop a new understanding of anything. However, this does not mean that all our prejudices are good. Bad prejudices are when we leap to conclusions, ignoring any evidence that might contradict our preunderstanding. In this way, Gadamer (1989, pp. 268-9) explicates that prejudices are necessary for any new critical understanding to take place insofar as one is open to new meanings and understandings:

All that is asked is that we remain open to the meaning of the other person or text. But this openness always includes our situating the other meaning in relation to the whole of our own meanings or ourselves in relation to it ... This kind of sensitivity involves neither "neutrality" with respect to content nor the extinction of one's self, but the foregrounding and appropriation of one's own fore-meanings and prejudices. The important thing is to be aware of one's own bias, so that the text can present itself in all its otherness and thus assert its own truth against one's own fore-meanings.

Accordingly, by paying critical attention to one's own prejudices in the fieldwork, we can say that a fieldworker enters a practice world with her own background practices. She has to remain open to the meaning of this new world, while foregrounding and appropriating her own fore-meanings and prejudices. It is important for her to be aware of her own biases so that she can allow the participants to assert their own truth against hers. Despite our prejudices, however, we have to allow the otherness of those in the field to speak to us such that we can attain an understanding of their own truth. 


\section{GRASPING THE LOGIC OF ENTRANCE}

The field is a complex world where ethnography occurs and where the ethnographer finds herself thrown (Geertz, 1973; Goffman, 1989). In our thrownness, following Heidegger (2011, pp. 26,44$)$, the entrance into the field can be critically grasped as "the [spatial] state one finds oneself in." When an ethnographer attempts to enter the field, the entrance is grounded in and entwined with her own fore-meanings and prejudices along with the fore-meanings and prejudices of the participants. An ethnographer is thus thrown into a situation, but it is precisely this thrownness that enables her to respond and make sense of the field as a practice world (Heidegger, 2008, pp. 219-224).

The concept of thrownness suggests that the authenticity of an ethnographer hinges on engaging with the field phenomena, getting involved in and doing the activities in the field insofar as "one is what one does" (Heidegger, 1985, p. 244; 2008, p. 283). Of course, it is neither possible nor desirable to truly gain the native point of view, rather the hope is that, through the appropriate entrance the gap between 'living like' and 'living with' the participants can be intimately closed (Van Maanen, 2011b). In this vein, authentic ethnographic fieldwork requires the fieldworker to be practically doing the fieldwork by being actively engaged with practices in the field (cf. Goffman, 1989). This point of engagement is crucial for any authentic fieldwork (Golden-Biddle and Locke, 1993, p. 599): a field researcher needs to be intimately involved with the participants' practices in the field as opposed to becoming a mere spectator of them (Klein and Myers, 1999, p. 74; cf. Van Maanen, 2011a).

Hence we can see the field is more than just a venue, and the fieldwork is more than the simple collection of data. Rather, the practice of fieldwork requires critically grasping what one does in it by understanding where one finds oneself and how one finds oneself in it. The extent to which we engage is delimited by our thrownness and the extent to which we engage with the fieldwork by doing the same activities as the participants. The concept of thrownness provides a tangible way for the field researchers to make sense of the field. 


\section{Being Thrown in the Field}

Geertz (1973, p. 13) says that "finding [one's] feet" is an important "personal experience" for ethnographic fieldworkers. When we are thrown into an unfamiliar situation, we need to find a firm place to stand on, but how do we start? If standing on our feet is something that we need to do in order to gain entrance into the field, where do we begin? The answer lies in the practically engaged logic of practices: Heidegger (2008, pp. 458ff) says we are thrown and find the world already there before us. Thus, in our everyday practices, by the virtue of our being-in-the-world, we are already in the world involved (Sandberg and Tsoukas, 2011, p. 350; cf. Schatzki, 2010); in other words, we are always already thrown in our everyday situations. As field researchers, we are thrown from one practice world to another. Rather than taking a detached conceptual position, we need to make sense of entrance through our engagement in the field. In thrownness, it is our horizons of understandings which, as shown earlier, help us make sense of the field, and help us find our feet.

We encounter the field on the basis of our preconceptions, i.e. our prejudice horizon. However, we are thrown, not just into an environment, but also into a historical moment in a practice world; thus, our prejudice horizon is fused with the historicity of the field. Therefore, when we first approach the field, we have but a factical understanding of the field phenomena. One can grasp the difference between factual and factical as follows: while the latter is our ways to be (researcher, mother), the former is its properties (male, female).

Dreyfus (1991, pp. 20-5) stresses that we can never be sure of our factical ways of understanding. In thrownness, our factical understanding of ourselves is always bound with others' factical understanding of the field - a nexus of practices, equipment, and entities which we encounter: our interpretation of phenomena in the field is their interpretation and vice versa. Heidegger (2008, p. 400) explains, 
[We get] dragged along in thrownness; that is to say, as something which has been thrown into the world, it loses itself in the "world" in its factical submission to that with which it is to concern itself.

Haar (1993) develops this idea further and points out that our standard response to being thrown is to get busy and engage ourselves in activities with one another. That is to say, we flee from anxiety by seeking shelter in the normativity of everyday practices. That is why it is problematic to start making sense of the field as soon as one gains access. Rather, field researchers are required to do things as the participants do. Dreyfus (1991, p. 236) says that we are thrown straight into the routine affairs of the field where the factical interpretation of practices matters more than a conceptual understanding. In a similar way, Ciborra and Willcocks (2006, p. 135) discuss thrownness in term of facticity and raise the significance of practices; they say the "concern for factical life expresses the re-balancing of activities," that is, an everyday understanding of activities takes precedence in the field. We can then say that it is our thrownness that enables us to interpret the meaning of our engagement with the participants in the field.

Further, when we find ourselves thrown into a practice world it often requires engagement with equipment, things, places, people, and practices. An appropriate initial response would be rather normative insofar as to follow established practices such as social or organizational norms before making sense of practices and, is so doing, before moving on to engage with phenomena in a meaningful way (cf. Heidegger, 2008, p. 190). Engagement with everyday practices hinges on a holistic understanding. Geertz (1973, p. 12) sheds light on the subtle intricacies of engagement and provides a practical example illustrating how a holistically engaged approach works:

To play the violin it is necessary to possess certain skills, habits, knowledge, and talents, to be in the mood to play, and (as the old joke goes) to have a violin. But violin 
playing is neither the habits, skills, knowledge, and so on, nor the mood, nor (the notion believers in "material culture" apparently embrace) the violin.

Geertz succinctly points out that playing the violin requires all of these things to come together at once; the whole performance is greater than the sum of the parts, and all need to be understood in a holistic harmony by interpreting phenomena against a background of associated practices. He applies this point to fieldwork: upon encountering an unfamiliar practice, the field researchers need to take an engaged holistic view of the field where the practice belongs before interpreting it. Further, a field researcher needs to understand the significance of entwined background practices insofar as often these remain invisible and require one to engage with practices in order to make sense of them. These 'nexuses' of background practices contain many things, purposes, norms and other sets of practices (Schatzki, 2010). In thrownness, the participant observation, thus, is not "at them" but "with them", as Boland (1985, p. 343). Boland says that in this way the "understanding comes step by step, layer by layer, as preconceptions, prejudices, and assumptions are recognized and seen through" (p. 343). Klein and Myers (1999, p. 74) go one step further and say that the participants, as well as the researchers, are interpreters and analysts insofar as "they alter their horizons by the appropriation of concepts used by [fieldworkers] interacting with them, and they are analysts in so far as their actions are altered by their changed horizons."

Hence, as field researchers, we find ourselves thrown in a field amidst intricate nexuses of practices of the participants and equipment. Although we might be only "temporary participants" in the field (Sandberg and Tsoukas, 2011, p. 350), in thrownness, the horizons of understandings of both the field researchers and the participants are entwined in the field. Next, we present some evidence from our ethnographic research to illustrate how entrance into the field can be understood as a rite of passage and interpreted as being thrown in a practice world. 


\section{RESEARCH METHOD}

\section{The Nature of the Field and Access to the Field}

We used ethnography to study the everyday technological practices of young professionals in an organizational setting. The site of the ethnography was a large technology services organization in Asia-Pacific, from here onwards called FieldTech. The fieldwork lasted just over eighteen months. The first author, from here onwards called the 'ethnographer,' was in the field from August 2013 to March 2015, at least three days a week. In accordance with the scope of the study, only the newest and youngest IT staff were considered. They were primarily newly hired graduates or people who were in their first year of employment at FieldTech.

The initial contact was made in July 2013. After the access negotiations, FieldTech agreed that ethnographic research might be of some value to their organization. In the thrownness perspective, our access had more than an element of good luck insofar as our research and the research site's organizational strategy were aligned (Van Maanen, 2011b. p. 84). In a sense, the horizons of understanding of the researchers and the researched were found to be fused together in a meaningful way. The ethnographer was then invited to join FieldTech's IT department as a software engineer to work part-time on a key on-going project with one of the software development teams (here onwards called FieldTeam), while on the other days he was free to focus on his research. Good access was thus granted by securing a working role in the field, being an active project member, and being at the coalface of the organization; it also meant that a fully sustained access was also granted to the organization's IT systems, spaces and staff. Further, IT infrastructural access was granted simply by the virtue of being a software engineer working on the project.

The move from access to entrance took a slow gradual course. Initially, the ethnographer was placed in FieldTech's flagship software development team, FieldTeam, to work on the 
ongoing IT project design issues. With a longstanding software engineering practitioner history, we found that the ethnographer was more often than not approached to work on various software design issues despite his temporary status in the organization. Thus, from the ethnographic immersion perspective, we can say we were fortunate to get the opportunity to be at the heart of the fusion of practices in the field from the very beginning. Further, being a working employee also established the ethnographer's position as an engaged interpreter (a team member) and not just a detached observer (Fine and Hallett, 2014; Anteby, 2013). Being a working employee allowed us to make sense of the practices from the inside, just like the participants.

Our access highlights two things. From a thrownness perspective, we can say that access involved interpretation of horizons of understanding, but it only paved the way toward entry did not guarantee entrance. Second, as we shall further elaborate, it established the role of the researcher in the field and determined the subsequent progress of the fieldwork.

\section{Data Collection and Analysis}

Engaged participant observation was the primary source of data. The daily field notes included "thick description[s]" (Geertz, 1973, pp. 3-30) of the events and practices in the field. The field notes also included notes of weekly meetings, informal chats as well as audio notes, videos, photographs, personal logs and official electronic records (e.g., project communications, video-conferencing, instant messaging, emails, graphic notes, and illustrations). The ethnographer also participated in two different recurring user group meetings. In addition to these sources, ten qualitative interviews were conducted with select participants. These interviews were conducted according to the guidelines provided by Myers and Newman (2007). The interviews were informal, candid and rather confessional in nature and lasted between an hour and two hours. All interviews were digitally recorded except one (on the request of the interviewee). The unrecorded interview was methodically reconstructed immediately after the session using interview notes and observation notes. 
The data were interpreted using hermeneutic analysis (Myers, 2004) and followed the hermeneutic principles for interpretive field studies (Klein and Myers, 1999).

In the following discussion, we present and engage with the ethnographic evidence primarily from the initial 270 hours of immersive observational data. This is the most relevant evidence pertaining to the entrance phase of the fieldwork.

\section{ENTERING THE FIELD}

As discussed earlier, there are many horizons of understanding in the field which determine one's thrownness. Some of the examples are everyday language, historicity, prejudice, temporality and spatiality among others. Here, we present the evidence for just two horizons namely, historicity and prejudice, to illustrate how the field researchers' entrance can be seen as being thrown in the ethnographic field.

\section{Horizon of Historicity}

We begin by expounding the historicity of the researcher. In our case, the ethnographer is also a seasoned programmer and has worked internationally in the corporate sector. During the initial contact with FieldTech, it was evident that the technical skills of the ethnographer were in line with the workplace IT practices of FieldTeam. Likewise, as stated earlier, our long-term research project objectives (i.e., studying of technological practices in organizations) were also somewhat closely aligned to FieldTech's organizational strategy. The horizon of historicity discloses that the field researcher was thrown in a somewhat familiar world and had some pre-understanding of the horizons of the participants. In line with the hermeneutic of thrownness, entrance into the field and integrating into FieldTeam quickly became transparent as the field notes from the first day reflect:

[one of the managers] commented on my query on the team's working hours: 'You know how they [developers] work...come on, you are one of us, you should know [laughs]." (Excerpt from the field notes). 
Being a researcher in an unfamiliar organization with a different culture can be challenging. Even the field researchers who once belonged to the larger practice world of the field face difficulties re-entering a rather familiar world (the Chicago school of fieldwork is full of such examples, for a general discussion see Anteby, 2013, p. 1285). But in this case, the ethnographer was described as 'one of us' on the very first day of fieldwork, ostensibly because of prior work experience and his historical background. Being called 'one of us' also meant that it was much easier than expected to get intimately in touch with the participants' horizons of understandings. This point further manifests itself in the candid and confessional nature of many informal chats and interviews. Consider the first encounter with a young programmer:

In my first coffee area talk, I was asked: "You are a programmer?" I saw her eyes widen with curiosity. I replied yes, but when I started to give my background, I was promptly and continuously interrupted: "Which [programming] languages?"... "Which [software development] framework?" She completely ignored the fact that I was introduced as a researcher just a day ago. [...] Her curiosity increased, as I provided details and was topped by a geeky compliment: "Ooh, C++ [programming language], very hard-core," she smiled, almost turning into a giggle.

[Later] when I asked her about [...] other team members, to my amazement I was told: "oh, you'll like them; they are like us, you know, programmers!" (Excerpt from the field notes)

What is interesting is the seemingly immediate change of perspectives of both the young programmer and the ethnographer. The significance of this change in practice is twofold. First, following Anteby (2013), we can see it as an instance of upholding ethnographic distance while remaining involved in the field. One minute the researcher is a complete stranger doing research and just starting to explain what his research project is about (ethnographic distance); the next minute he is 'like us' and counted as being one of the team 
(ethnographic involvement). Without understanding the fusion of horizon, without critically understanding our thrownness, it is rather difficult to be involved while keeping distance in the field. Second, we acknowledge the everyday aspect of this critical dialogue. Of course, this could be just a simple matter of luck or courtesy. Nonetheless, it does seem to indicate a fusion of horizons of both the ethnographer and the participants. In this case, it is the historical fact that both parties have a background in software development that is itself grounded in a certain set of practices, and it is that which establishes the dialogue.

Although the role as a researcher was clearly mentioned in the official introduction to the team, the young programmer seemed to forget about this and from then on simply treated the researcher as a fellow software engineer (since the ethnographer was working part-time as one while also conducting the field research). The other programmers reacted in the same way as the first one: none brought up the subject of research but seemed more interested in knowing about the ethnographer's computer science background. We can say that the horizon of historicity persists in the participants' perspective. This historicity facilitated a prompt integration into the team as 'one of us' and paved the way toward engaged participation. It was no coincidence that we found the participants tended to became rather comfortable despite the presence of the researcher in the field. During project meetings and gatherings, as early as in the first week, it allowed us to capture the evidence from within, up close and personal (see Figure 2). The participants' understanding of the ethnographer was formed from the very first day of the fieldwork and influenced the entire period of fieldwork that followed.

\section{[insert Figure 2 about here]}

In the light of the above, using the idea of historicity in thrownness, we can say that the ethnographer in this case quickly found his feet, but this was only because of the shared background practices. Conversely, we suggest that it could be much more difficult for a field researcher to find their feet if there was little or no tangible link between the participants and 
researcher's histories; a fusion of horizons in the field would take longer to manifest and be more difficult to grasp. From the outset this might appear as a trivial observation, but the point is, precisely, to highlight the criticality of the everyday aspects of the fieldwork such as historicity. Such details are often bracketed out as the focus is set on the phenomena in the foreground. However, for a field researcher, neglecting to pay attention to the fusion of horizons could mean that she gets lost in the field and loses her orientation.

Using our phenomenological hermeneutic lens, we can say that the historicity determines the thrownness and this thrownness is based on the fore-structure of understanding. Table 1 summarizes the movement of understanding that took place when the researcher entered the field. First, the participants already belonged to a project team (FieldTeam) and thus, the software development background of all the participants, the norms and culture of being a software engineer and so forth are simply taken for granted (fore-having). The ethnographer too had belonged to many different software development teams before joining FieldTeam and thus his background was also connoted. Second, the fact that all the participants and the ethnographer had this shared background meant that the people immediately made certain assumptions about the researcher from the very first encounter (fore-sight). They simply assumed that he already knew about the nature of work, work practices, and work roles in a software development environment - there was apparently no need to explain how the team worked. Third, the fore-having and the fore-sight led to the participants now having certain expectations about what the field researcher would do (fore-conception). Since the ethnographer had previous organizational work experience in software development, the participants simply expected him to be already familiar with software coding practices and hence it was seen as a critical field moment which allowed him to integrate smoothly into the local team. Of course, these expectations of the field researcher then needed to be fulfilled (Coffey, 1999, pp. 88-9). The actualization of expectation is achieved through engagement with everyday practices and demonstrating that the researcher is indeed 'one of them' by 
getting involved in the work during the fieldwork and engaged with the phenomena as expected.

\begin{tabular}{|c|c|c|c|}
\hline & fore-having & fore-sight & fore-conception \\
\hline \multirow[t]{2}{*}{ Participants } & Project Team & Work roles & Local familiarity \\
\hline & e.g. FieldTeam & programmers, managers & e.g., coding practices \\
\hline Researcher & $\begin{array}{l}\text { Software } \\
\text { development } \\
\text { teams }\end{array}$ & $\begin{array}{l}\text { Ethnographer } \\
\text { team member, software engineer }\end{array}$ & $\begin{array}{l}\text { Historical familiarity } \\
\text { corporate IT experience }\end{array}$ \\
\hline
\end{tabular}

Table 1. Fore-structure of Horizon: Historicity

By spelling out the components of the fore-structure of the horizon of historicity we observe how a researcher's engagement with participants in the field is grounded deeply in the historicity of everyday practices. Further, it shows how the field is entwined with the practices of both the researcher and the participants. As a researcher begins to engage with the fieldwork, it is the dialectical interactions within this horizon that enable understanding. The pre-understandings of the participants and the researchers are part of an on-going dialectic.

Having presented some evidence for the horizon of historicity, we now engage with evidence for the horizon of prejudice, to illustrate further how the field researchers' entrance can be seen as being thrown in the ethnographic field.

\section{Horizon of Prejudice}

As a working member of FieldTeam, the ethnographer was asked to shadow and then to proceed to manage an on-going technological change; this was simply due to an unforeseen human resource issue. However, this task assignment is a practical example of a 'good prejudice' insofar as the managers had a positive pre-understanding of the researcher's skills. Part of the work required the ethnographer to attend meetings with IT stakeholders from other involved teams (in this case, FieldGroup). In one such meeting, there was a brief discussion about what advice the ethnographer might be able to give, to counter arguments from FieldGroup. Here we observe the significance of horizon of prejudice: the ethnographer is asked to support a social group in the field (FieldTeam) based on assumptions (prejudice) 
about the researcher's current role and previous practical experience (horizon of historicity). In this way, it was possible to disclose how subtly the two horizons fused transparently in practice.

Regarding the above, consider this excerpt from the follow up meeting with a senior manager, which occurred soon after the intradepartmental meeting with FieldGroup representatives.

[the manager] said that he is really glad that finally "a real dialog" has started between FieldTeam and other teams [i.e., FieldGroup]. When I asked him to unpack what he means, he explained that sometimes the developers [in FieldTeam] are so quiet in saying their mind [or immersed in their everyday practices], "they'll ignore everything as long as their code is compiling." He continued to say that in such situations it is impossible to let others know what their point of view is... since no one says 'what the problem is'. He then thanked me politely and said that he really needs "someone who knows the developers' perspective, someone who speaks for the developers." (Excerpt from the meeting notes)

We observe how good prejudice discloses the developing intimacy with field practices vis-àvis an entrusting expectation (fore-conception) in the field inasmuch as the ethnographer is seen as someone who might be able to 'speak for' the participants, facilitate dialogue and, in effect, present a plausible account of their perspective. Indeed, the practice of fieldwork can be seen as an ongoing dialogue between the ethnographers and the participants (Clifford, 1983). A dialogue that is engaged polyvocality insofar as the ethnographic voice is an entwinement of many voices in the field, of participants as well as the field researchers (Clifford, 1988). In the same vein, toward the end of the meeting, the same subject came to the fore again as the manager disclosed by, 
...referring to the [earlier] argument with FieldGroup, [he says] it's good to have "this debate" and how "no one dares says anything, no one says their point of view," [and] that after such discussions, only then, "we can find a 'common ground' which will help us... building better IT systems."

...When I was about to leave, he revealed that "Jim is the quiet one, I know his personality, that's why I put you with him, so you have to do a lot of talking," I told him that I understand and will make sure we are all on the same page all the time, he nodded back and I moved back to my desk. (Excerpt from the meeting notes)

At first glance, this conversation seems a matter of workplace openness. However, applying the thrownness lens, we see that the ethnographer is thrown in the world a) against the horizon of prejudice and b) the prejudice reveals others' (participants) positions in the horizon. That is, first, the prejudice discloses the work habits of the participants, which is not a negative thing but simply their absorption in practices. Along the same lines, the researcher's counsel is sought, by the virtue of good prejudice (from our point of view), as it is grounded in rituals concerning standard technology practices which are otherwise overlooked in developers' everyday technological habits. For instance, here the ethnographer is already familiar with software practices' rules and regulations which the developers usually take for granted. Thus, the prejudice laden decision of a manager led to a larger fusion of horizons, that is, an intra-team dialogue between FieldTeam and FieldGroup.

Table 2 summarizes the movement of understanding with respect to the horizon of prejudice. Note that the fore-structure of the prejudice of participants is highly contextualized to their team, which is the practice world where they belong. Fore-having is what the team members and the researcher already have and take for granted. For example, they already have the certain IT equipment within FieldTeam and a historical background of using this equipment. Fore-sight is the assumptions that are made by the participants and the researcher; they include habitual practices such as workplace norms. Fore-conception is the participant's and 
the researcher's expectations e.g. their expectations regarding the team adhering to certain milestones during the FieldTeam's project work.

\begin{tabular}{|llll|}
\hline Participants & fore-having & fore-sight & fore-conception \\
& Equipment & Habitual & Use \\
& e.g., FieldTeam IT & e.g., workplace norms & e.g., project work \\
\hline Researcher & Equipment & Ritual & Purpose \\
& FieldTech IT & programming practices & $\begin{array}{l}\text { organizational } \\
\text { ethnography }\end{array}$ \\
\hline
\end{tabular}

Table 2. Fore-structure of Horizon: Prejudice ethnography

We note that the ethnographer is thrown head first into the field inasmuch as he is freely asked to support FieldTeam in an on-going dialogue with another team, despite the acknowledged status of field researcher as independent and, to some extent as Sandberg and Tsoukas (2011) put it, a 'temporary participant' in the field practices. The upshot, nonetheless, is that the local horizons of participants fuse with the horizons of understanding of the field researcher, and both are driven by their corresponding prejudices. This fusion of horizons facilitates a change of status of ethnographer in the field and can be seen as a rite of passage in a practice world. The ethnographer moves from being a participant observer to a meaningful part of the holistic whole that is the practice world of the participants.

Consistent with the concept of thrownness, the intricacies of the fore-structure of the horizons of understanding presented here suggest that a) there is a dialectical interaction in the field practices which field researchers encounter in their entrance and b) in order to interpret this dialectic, both the researchers' and participants' perspectives need to be taken into account.

\section{DISCUSSION}

The purpose of this paper has been to shed some light on a field researcher's entrance into the field and how it can be theorized. We have used the concept of thrownness from Heidegger along with the hermeneutic concepts of historicity and prejudice to illuminate the practice of entrance as a rite of passage into a complex practice world. As we have seen, 
entrance into the field influences how an ethnographer initially engages with the participants in the research site; precisely, the entrance orientates the ethnographers in the field that then holds sway during the course of the fieldwork.

\section{Entrance versus Access}

Many qualitative researchers have discussed the topic of gaining access to a field site; insofar as gaining access can be a challenge, various suggestions have been made as to how the problem of access can be overcome (e.g., Walsham, 2006; Gobo, 2008; Myers, 2013). However, as we have demonstrated, access to a field site is not the same as gaining entrance into the field. Whereas 'access' involves gaining permission to conduct research in a particular field setting, entrance is a rather engaged practice of what you see (and how you are seen) and what you do (and are asked or allowed to do) when you get there after gaining access. In the same vein, while good access still requires "co-operation" from the participants (Pole and Hillyard, 2016, p. 27), entrance is about stepping into the practice world of participants. Hence, access and entrance into an ethnographic space are two different things. While gaining access can be best seen as an administrative concern (Gobo, 2008, p. 118-126; Neyland, 2008, pp. 63-65), entrance is a complex phenomenological enterprise that involves engaging with the practice world of participants, requiring researchers to be sensitive to field practices in the field.

Entrance is also shown to be entwined with the historicity of the researcher. For example, it would be possible, for a field researcher, to gain access to a research site (in our case, FieldTech), but then a researcher without some practical experience of the field practices (in our case, software development practices) would not be regarded as 'one of us' from early on in the fieldwork. Also, it is unlikely that such a person would be asked to give advice in order to counter the arguments of another group within the field (e.g., another project team); this is not to say that being regarded as an outsider or as not being 'one of them' is 
necessarily a bad thing. Nonetheless, it does suggest that entrance into the field largely determines what the field researchers see and find out.

Hence, the first contribution of this paper is to suggest that entrance marks a critical field moment in qualitative research methods where field research is conducted. We have shown that there is not one, but two distinct initial phases of qualitative field research namely, access and entrance. These phases broadly relate to getting in (access) and being there (entrance) in the field. Both phases are equally important in enabling the field researchers to immerse themselves in the world of participants, but the one should not be confused with the other.

\section{Rite of Passage}

The second contribution of this paper is to show that entrance marks the transition, not only from one phase to another, but also from one status to another. That is, entrance is a rite of passage that determines what the field researchers see and do and how they are seen by the others. In our case, entrance into the field marked a change of status from being an outsider to being 'like us' and being 'one of us'; from that moment onwards the field was seen as a world to be in. Of course, the notion of the entire period of ethnographic fieldwork being a rite of passage has long been an important theme in anthropology (Hammersley and Atkinson, 2007), but the idea that entrance into the field can also be seen as a rite of passage is new to the IS research literature on qualitative research methods. Through this rite of passage, a field researcher aims to be one with the participants rather than embarking on the quest to become one of the participants (Geertz, 2000). Here, it is the thrownness of the fieldworkers, by orientating them in the field in order to achieve the entrance, which determines how immersive a researcher can be with the participants in their practice world. 


\section{Thrownness in the field}

Our third contribution is theoretical: we have used Heidegger's concept of thrownness to provide a way of conceptually grasping the entrance as a rite of passage. The thrownness lens provides the possibility to understand the field as a complex world where a field researcher needs to place herself in a way that the world makes sense to her.

Using thrownness as a conceptual lens, fieldworkers can also become aware of their own historicity and prejudices. As they engage in a dialogue with the participants, being aware of their own prejudices and acquiring a disposition of becoming attuned to the various voices in the field should help them to be open to new meanings and understandings. Ethnographic awareness in the field lets fieldworkers know their position in the field and from that position they can begin to approach and make sense of field practices. Thrownness suggests that awareness is an engaged practice rather than a detached state that one achieves simply by observing raw facts, data or events in the field. Entering the practice world of the participants allows fieldworkers to 'be in the situations' in the field (Goffman, 1989). Grasping entrance through thrownness empowers the fieldworkers to be there in the field rather comfortably, and hence, in effect, be at home in the world of the participants (cf. Van Maanen, 2011a). By acknowledging and understanding one's thrownness in a situation, an ethnographer can critically engage with the field practices 'along with' the participants instead of reporting on them as a mere spectator in the field.

\section{Research Instrument Calibration}

In ethnographic research, the researcher is the primary data collection instrument; hence this 'instrument' needs to be 'calibrated' (Myers, 2013, pp. 139, 187; Conquergood, 1991, p. 180). Accordingly, a plausible ethnography is one where the readers knows how the research instrument was calibrated: whom did the field researcher talk to, what did they do, where were they, how did they arrive there, and how long were they in the field, and so forth. 
Hence the fourth contribution of this paper is to make 'instrument calibration' explicit in qualitative field research methods. This aspect tends to be ignored as field researchers simply presume that the researcher is already 'calibrated' by virtue of their academic training. However, as Fine and Hallett (2014) point out, entering the ethnographic field from academia is like being thrown from one field to another field. While academic training is essential, it only helps to a certain extent (Fine and Hallett, 2014, p. 89). A field researcher still needs the practical experience of being there in the field and to become engaged with everyday practices. The concept of thrownness provides one such methodological tool to get intimately closer to phenomena in the field. Further, it can help researchers identify and acknowledge distinct horizons of understanding and, in so doing, become aware of and 'calibrate' their position in the field. Only an ethnographic research instrument that is appropriately calibrated in the field can authentically conduct the fieldwork (Golden-Biddle and Locke, 1993).

Entrance into the field entails engagement with a series of critical field moments during which whatever 'calibration' takes place influences the entire period of fieldwork. On the one hand, as we have said earlier, the researchers need to become aware of their own historicity and prejudices. Prior to beginning a study of the others, the researcher must first study herself. On the other hand, the researcher is not just studying herself; she is there to learn about the social, historical and cultural practices of the participants. Hence the ethnography is not merely a confessional account of one's own personal experiences (which could be based on 'bad prejudices'), but nor is it an objective account of the field 'out there.' Rather, the completed ethnography represents the written account of the dialogue between the field researchers and the participants; a dialogue that is always polyphonic insofar as the ethnographic voice is an entwinement of voices, of participants as well as that of the field researcher (Clifford, 1983, 1986). A plausible ethnography is one where the nature of this dialogue is explored, and instrument calibration made explicit. This is also consistent with the 
principle of interaction between the researchers and the subjects in interpretive field research, as suggested by Klein and Myers (1999).

\section{Practical Implications}

We suggest that the concept of thrownness, as applied to entrance into the field, has some practical implications for field researchers. First, the thrownness lens enables field researchers to acknowledge and make explicit their own prejudices and assumptions; this in turn should help them to critically understand some of the other horizons in the field such as everyday language, spatiality, temporality and so forth (Gadamer, 1989). It is by fusing the horizons of understanding that the nature of practices comes to the fore and these, then, become available for interpretation and inquiry. Also, acknowledging historicity enables the researcher to do the fieldwork along with the participants in the practice world instead of, as Miettinen et al. (2009, p. 1315) put it, becoming a 'mere observant' of the field practices.

Second, the hermeneutics of thrownness enables the field researchers, when entering the field, to find their feet as quickly as possible. It also encourages them to track and address anomalies by

i) moving away from the literal meaning of phenomena,

ii) deferring judgement until the interpretation is clear and,

iii) opening up avenues for further analysis.

Third, employing the concept of the hermeneutic circle in one's entrance into the field paves the way to practically incorporate metaphor and narrative in an ethnographer's account of their fieldwork (Dreyfus, 1991, p. 36; cf. Ricœur, 1991). The best way to explain the fieldworker's thrownness is by providing a polyphonic narrative of their entrance into the field (Clifford, 1986). For example, using the horizon of prejudice, we have shown that, in the hermeneutic circle, there are always more voices than one entwined in a meaningful whole.

Field researchers can also use the vocal horizon of understanding to highlight the 
participants' voices, identify their own voice, give voice to 'the others' and, in effect, attempt to bring ethnographic polyphony in the field evidence to the fore (Clifford, 1988). The ethnographic narrative is sometimes reduced to a simple reproduction of evidence or direct quotes, but we suggest that field researchers need to go beyond this and critically engage with the polyphonic nature of their ethnographic evidence.

\section{Limitations and Future Research}

We acknowledge some limitations of our study. One obvious limitation is that our findings are from a single period of fieldwork in one ethnographic research project only. Another is that there was only one researcher on-site. Despite this, we believe our findings may be relevant to all kinds of fieldwork inasmuch as the concept of the field is central to many qualitative research methods.

One possible avenue for future research would be to study exit from the field using the thrownness lens. Like entrance, exiting the field is an important phase in ethnographic field research (Michailova et al., 2014). In particular, as field researchers attempt to return to the academic world, using the concept of rite of passage can help explain how the change in a researcher's status influences interpretations, data analyses, and compilation of the ethnographic account.

Another fruitful avenue of research could be to apply and extend our work to consider entrance into symbolic, digital and virtual spaces. Scholars might also want to explore the problems of entrance where automatic access is usually given such as in autoethnography or at-home ethnography (Alvesson, 2009). Automatic access might not necessarily guarantee automatic entrance into the epistemic core of the research phenomena. There are complex power structures and conflicting horizons of understanding that can threaten the plausibility of the fieldwork (Karra and Phillip, 2008). New conceptualizations of entrance in autoethnography might be required. 


\section{CONCLUSION}

In this paper we have discussed entering the field as a rite of passage that represents a transition in the life of a field researcher. Much more than access, entrance into the field determines how the researcher is able to engage with the participants and field practices. The entrance largely determines what the field researchers see and do, and how they are seen and understood by the others in the field. One implication of our theorizing is that, before a field researcher enters the field, it is crucial to develop some understanding of the world where she is to be thrown. The field researchers also need to become aware of their own historicity and prejudices as they engage in a dialogue with the participants. Another way of saying this is that the plausibility of an ethnographic account is improved if we know how the 'research instrument' (the field researcher) was 'calibrated.' Further, in addition to learning the social and cultural practices of the participants, field researchers also need to remain open to new meanings and understandings. Our hope is that this paper will enable field researchers conducting fieldwork to find their feet quickly, to remain open to new interpretations, and above all to feel at home in the practice world that is their research site.

\section{REFERENCES}

Alvesson, M. (2009) At-Home Ethnography: Struggling with Closeness and Closure. In: Organizational Ethnography. (Ybema, S., Yanow, D., Wels, H., and Kamsteeg, F. (eds)) SAGE, London, pp. 156-175.

Anteby, M. (2013) Relaxing the Taboo on Telling Our Own Stories: Upholding Professional Distance and Personal Involvement. Organization Science, 24, 1277-1290.

Baskerville, R. L. \& Myers, M. D. (2015) Design ethnography in information systems. Information Systems Journal, 25, 23-46.

Bell, G., Blythe, M. \& Sengers, P. (2005) Making by making strange: Defamiliarization and the design of domestic technologies. ACM Transactions on Computer-Human Interaction, 12, 149-173. 
Boland, R. J., Jr. (1985) Phenomenology: A preferred approach to research on information systems. In: Research methods in information systems. (Mumford, E., Hirschheim, R., Fitzgerald, G., and Wood-Harper, A. T. (eds)) Elsevier, Amsterdam.

Boland, R. J., Jr. \& Tenkasi, R. V. (1995) Perspective Making and Perspective Taking in Communities of Knowing. Organization Science, 6, 350-372.

Ciborra, C. \& Willcocks, L. P. (2006) The mind or the heart? it depends on the (definition of) situation. Journal of Information Technology, 21, 129-139.

Clifford, J. (1983) On Ethnographic Authority. Representations, 1, 118-146.

Clifford, J. (1986) On Ethnographic Allegory. In: Writing culture: The poetics and politics of ethnography. (Clifford, J., and Marcus, G. E. (eds)) University of California Press, Berkeley, pp. 98-121.

Clifford, J. (1988) The predicament of culture: twentieth-century ethnography, literature, and art. Cambridge, Harvard University Press.

Coffey, A. (1999) The ethnographic self: Fieldwork and the representation of identity. London, SAGE.

Cole, M. \& Avison, D. (2007) The potential of hermeneutics in information systems research. European Journal of Information Systems, 16, 820-833.

Conquergood, D. (1991) Rethinking ethnography: Towards a critical cultural politics. Communication Monographs, 58, 179-194.

Dourish, P. \& Bell, G. (2007) The infrastructure of experience and the experience of infrastructure: meaning and structure in everyday encounters with space. Environment and Planning B: Planning and Design, 34, 414-430.

Dreyfus, H. L. (1991) Being-in-the-world: A Commentary on Heidegger's Being and Time, Division I. MIT Press.

Fine, G. A. \& Hallett, T. (2014) Stranger and stranger: creating theory through ethnographic distance and authority. Journal of Organizational Ethnography, 3, 188-203.

Gadamer, H.-G. (1989) Truth and Method. 2nd rev edn. New York, Crossroad. 
Geertz, C. (1973) The interpretation of cultures. New York, Basic Books.

Geertz, C. (2000) Local knowledge: further essays in interpretive anthropology. 3rd edn. New York, Basic Books.

Gobo, G. (2008) Doing Ethnography. London, SAGE.

Goffman, E. (1989) On Fieldwork. Journal of Contemporary Ethnography, 18, 123-132.

Golden-Biddle, K. \& Locke, K. (1993) Appealing Work: An Investigation of How Ethnographic Texts Convince. Organization Science, 4, 595-616.

Gupta, A. \& Ferguson, J. (eds) (1997) Anthropological Locations: Boundaries and Grounds of a Field Science. University of California Press, Berkeley, CA.

Haar, M. (1993) The Enigma of Everydayness. In: Reading Heidegger: commemorations. (Sallis, J. (ed)) Indiana University Press, Bloomington, pp. 20-28.

Hammersley, M. \& Atkinson, P. (2007) Ethnography: Principles in Practice. 3rd edn. London, Routledge.

Harrington, B. (2003) The Social Psychology of Access in Ethnographic Research. Journal of Contemporary Ethnography, 32, 592-625.

Heidegger, M. (1985) History of the concept of time: prolegomena. Bloomington, Indiana University Press.

Heidegger, M. (2008) Being and Time. 7th German edn. New York, HarperPerennial/Modern Thought.

Heidegger, M. (2011) The concept of time. London, Continuum.

Jones, M. (2014) Researching Organizations: The Practice of Organizational Fieldwork. London, SAGE.

Karra, N. \& Phillip, N. (2008) Researching "Back Home": International Management

Research as Autoethnography. Organizational Research Methods, 11, 541-561.

Klein, H. K. \& Myers, M. D. (1999) A set of principles for conducting and evaluating interpretive field studies in information systems. MIS Quarterly, 23, 67-94. 
Kunda, G. (2013) Reflections on becoming an ethnographer. Journal of Organizational Ethnography, 2, 4-22.

Lee, J. C. \& Myers, M. D. (2004) Dominant actors, political agendas, and strategic shifts over time: a critical ethnography of an enterprise systems implementation. The Journal of Strategic Information Systems, 13, 355-374.

Marcus, G. E. (2009) Notes toward an ethnographic memoir of supervising graduate research through anthropology's decades of transformation. In: Fieldwork is Not what it Used to be: Learning Anthropology's Method in a Time of Transition. (Faubion, J. D., and Marcus, G. E. (eds)) Cornell University Press, Ithaca, pp. 1-34.

Michailova, S., Piekkari, R., Plakoyiannaki, E., Ritvala, T., Mihailova, I. \& Salmi, A. (2014) Breaking the Silence About Exiting Fieldwork: A Relational Approach and its Implications for Theorizing. Academy of Management Review, 39, 138-161.

Miettinen, R., Samra-Fredericks, D. \& Yanow, D. (2009) Re-Turn to Practice: An Introductory Essay. Organization Studies, 30, 1309-1327.

Moeran, B. (2009) From participant observation to observant participation. In: Organizational Ethnography: Studying the Complexity of Everyday Life. (Ybema, S., Yanow, D., Wels, H., and Kamsteeg, F. (eds)) SAGE, London, pp. 139-155.

Myers, M. D. (1999) Investigating information systems with ethnographic research. Communications of the AIS, 2, 1-20.

Myers, M. D. (2004) Hermeneutics in information systems research. In: Social theory and philosophy for information systems. (Mingers, J., and Willcocks, L. (eds)) Wiley, Hoboken, N.J., pp. 103-128.

Myers, M. D. (2013) Qualitative Research in Business and Management. 2nd edn. London, SAGE.

Myers, M. D. \& Newman, M. (2007) The qualitative interview in IS research: Examining the craft. Information and Organization, 17, 2-26. 
Nandhakumar, J. \& Jones, M. (1997) Too close for comfort? Distance and engagement in interpretive information systems research. Information Systems Journal, 7, 109-131.

Neyland, D. (2008) Organizational Ethnography. London, SAGE.

Oreglia, E. \& Srinivasan, J. (2016) Intermediaries, and the transformation of gendered power structures. MIS Quarterly, 40, 501-510.

Pole, C. \& Hillyard, S. (2016) Doing Fieldwork. London, SAGE.

Rabinow, P. (2007) Reflections on fieldwork in Morocco. 30th anniversary edn. Berkeley, CA, University of California Press.

Rabinow, P. \& Stavrianakis, A. (2013) Demands of the day: on the logic of anthropological inquiry. Chicago, The University of Chicago Press.

Reeves, C. L. (2010) A difficult negotiation: fieldwork relations with gatekeepers. Qualitative Research, 10, 315-331.

Ricœur, P. (1991) From Text to Action. Northwestern University Press.

Sandberg, J. \& Tsoukas, H. (2011) Grasping the logic of practice: Theorizing through practical rationality. Academy of Management Review, 36, 338-360.

Schatzki, T. R. (2006) The time of activity. Continental Philosophy Review, 39, 155-182.

Schatzki, T. R. (2010) The timespace of human activity: on performance, society, and history as indeterminate teleological events. Lanham, Md, Lexington Books.

Schultze, U. (2000a) A confessional account of an ethnography about knowledge work. MIS Quarterly, 24, 3-79.

Schultze, U. (2000b) Reflexive ethnography in information systems research. In: Qualitative Research in IS: Issues and Trends: Issues and Trends. (Trauth, E. M. (ed)) IGP, Hershey, PA, pp. 78-103.

Schwartz-Shea, P. \& Yanow, D. (2009) Reading and writing as method: In search of trustworthy texts. In: Organizational ethnography: Studying the complexities of everyday life. (Ybema, S., Kamsteeg, D., Wels, H., and Kamsteeg, F. (eds)) SAGE, London, pp. 56-82. 
Sluka, J. A. \& Robben, A. C. G. M. (2012) Fieldwork in cultural anthropology: An introduction. In: Ethnographic fieldwork: An anthropological reader. (Robben, A. C. G. M., and Sluka, J. A. (eds)) 2nd edn. Wiley-Blackwell, West Sussex, pp. 1-28.

Trigger, D., Forsey, M. \& Meurk, C. (2012) Revelatory moments in fieldwork. Qualitative Research, 12, 513-527.

Turner, V. W. (1974) Liminal to Liminoid, in Play, Flow, and Ritual: An Essay in Comparative Symbology. Rice University Studies, 60, 53-92.

Turner, V. W. (1997) The Ritual Process: Structure and Anti-Structure. 7th edn. Ithaca, Cornell University Press.

Van Gennep, A. (1977) The Rites of Passage. Paperback ed.. edn. London, Routledge and Kegan Paul.

Van Maanen, J. (2011a) Ethnography as Work: Some Rules of Engagement. Journal of Management Studies, 48, 218-234.

Van Maanen, J. (2011b) Tales of the Field: On Writing Ethnography. 2nd edn. Chicago, University of Chicago Press.

Walsham, G. (2006) Doing interpretive research. European Journal of Information Systems, 15, 320-330.

Ybema, S., Kamsteeg, D., Wels, H. \& Kamsteeg, F. (eds) (2009) Organizational Ethnography: Studying the Complexities of Everyday Life. SAGE, London. 


\section{ISJ 1214r2 - Authors' response to the editors and reviewers}

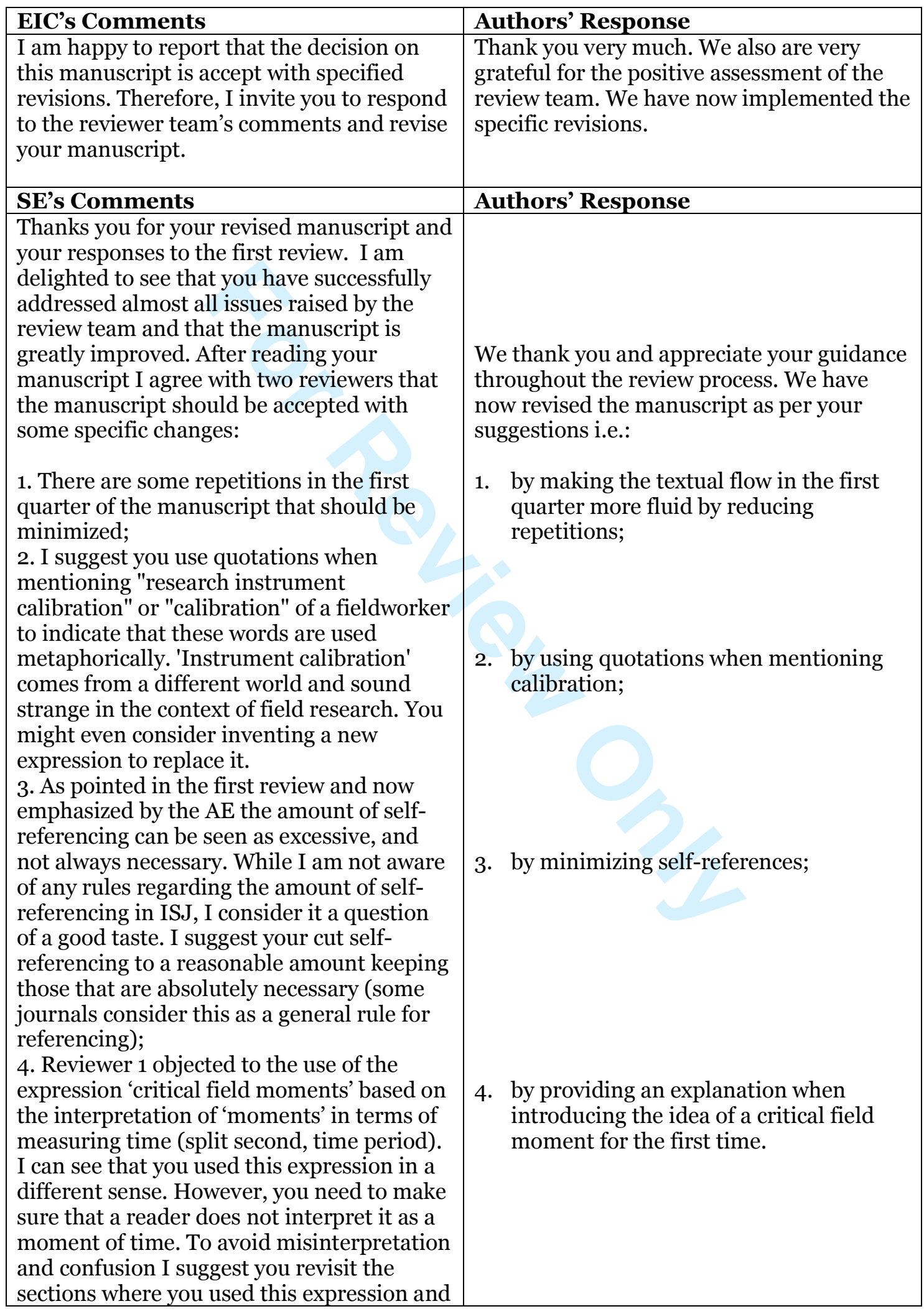




\begin{tabular}{|c|c|}
\hline $\begin{array}{l}\text { Apart from these minor issues the } \\
\text { manuscript is well written, interesting and } \\
\text { relevant for qualitative research practice. } \\
\text { After completing the above changes the } \\
\text { manuscript should be ready for publication. } \\
\text { (A note regarding reviewer } 2 \text { comment on } \\
\text { "taking a leaf": it is an expression meaning } \\
\text { "imitating'.) }\end{array}$ & Thank you once again. \\
\hline AE's Comments & Authors' Response \\
\hline $\begin{array}{l}\text { The paper has improved, but would still } \\
\text { require revision as pointed out by the expert } \\
\text { reviewers. The paper should be revised } \\
\text { according before it could be considered for } \\
\text { ISJ. We also noted an annoyingly large } \\
\text { amount of self referencing; consider } \\
\text { reducing by emphasising the papers merits. }\end{array}$ & $\begin{array}{l}\text { Thanks for your positive comments. We } \\
\text { have now implemented the specific } \\
\text { revisions as per yours and SE's suggestions. }\end{array}$ \\
\hline Reviewer 1 & Authors' Response \\
\hline $\begin{array}{l}\text { Dear authors, thank you for a much } \\
\text { improved paper. I have only very few } \\
\text { comments: }\end{array}$ & Thanks. Your insights have helped us a lot. \\
\hline $\begin{array}{l}\text { - the title of the paper could have the term } \\
\text { thrownness instead of rite of passage }\end{array}$ & $\begin{array}{l}\text { Our original title included thrownness. } \\
\text { However, an emphasis on thrownness } \\
\text { might be misinterpreted to treat entrance as } \\
\text { a philosophical concept only rather than a } \\
\text { practical one. We hope that the rite of } \\
\text { passage in the title will encourage the field } \\
\text { researchers to think critically about their } \\
\text { fieldwork. }\end{array}$ \\
\hline $\begin{array}{l}\text { - why don't you cite van Gennep for rite of } \\
\text { passage? }\end{array}$ & $\begin{array}{l}\text { We have now cited Van Gennep's seminal } \\
\text { work supported by Victor Turner. }\end{array}$ \\
\hline $\begin{array}{l}\text { - whilst in much of the paper the idea of } \\
\text { entrance is clearly expressed, there is still } \\
\text { some confusion regarding difference } \\
\text { between entrance and immersion? please be } \\
\text { clear about this from beginning on. }\end{array}$ & $\begin{array}{l}\text { We now provide an explanation to } \\
\text { distinguish entrance from immersion. }\end{array}$ \\
\hline $\begin{array}{l}\text { page 19, fourth line from bottom, "taking a } \\
\text { leaf" - do you mean leave? Maybe you can } \\
\text { drop the first part of the sentence, as you by } \\
\text { no means leave anthropological scholarship } \\
\text { here but return to it several times. }\end{array}$ & $\begin{array}{l}\text { Thank you for highlighting this subtle point. } \\
\text { We used it very carefully, according to the } \\
\text { Cambridge dictionary the expression can } \\
\text { also mean "to copy something that someone } \\
\text { else does because it will bring you } \\
\text { advantages." Still, to avoid any confusion, } \\
\text { we have now revised the phrase as per your } \\
\text { suggestion. }\end{array}$ \\
\hline $\begin{array}{l}\text { Figure } 1 \text { is nice but it could be developed to } \\
\text { include the fore-structures. }\end{array}$ & $\begin{array}{l}\text { We agree and we intend to extend it further } \\
\text { in future theorizing. An expanded figure, at } \\
\text { least in the current paper, would have } \\
\text { pushed the discussion toward the }\end{array}$ \\
\hline
\end{tabular}




\begin{tabular}{|c|c|}
\hline & $\begin{array}{l}\text { intricacies of the fore-structures, which is } \\
\text { why we kept it succinct. }\end{array}$ \\
\hline Reviewer 2 & Authors' Response \\
\hline $\begin{array}{l}\text { My comments in the previous review have } \\
\text { all been addressed, except for the notion of } \\
\text { 'moment' in relation to entrance. If the } \\
\text { authors check where they have used this } \\
\text { expression (pages } 7,9,17,25,30,31 \text { etc) } \\
\text { they will see that there are several different } \\
\text { mentions of 'moments' when entrance } \\
\text { would appear to have been achieved (either } \\
\text { in reference to the research literature or by } \\
\text { reference to the case - e.g. knowledge of } \\
\text { software coding practices on page 25.) }\end{array}$ & $\begin{array}{l}\text { Based on your suggestion and a helpful } \\
\text { pointer by R1 regarding Van Gennep's } \\
\text { seminal work, we have now provided a } \\
\text { further explication and references to clarify } \\
\text { the confusion around field moments. }\end{array}$ \\
\hline $\begin{array}{l}\text { The authors response to the comment re } \\
\text { 'moment' in my earlier review is as follows } \\
\text { "We have now updated the initial } \\
\text { discussion to explain that the critical } \\
\text { fieldwork moments relate to the distinct } \\
\text { phases of ethnography" which indicates that } \\
\text { they perhaps misunderstood my comments. } \\
\text { I meant that the use of the word 'moment' } \\
\text { (ie, split second, instant, etc) in relation to } \\
\text { 'entrance' is misleading. }\end{array}$ & $\begin{array}{l}\text { Sorry for the misunderstanding. We fully } \\
\text { agree with you and did not intend that the } \\
\text { notion of moment be taken as something } \\
\text { instantaneous. Indeed, this is the position } \\
\text { of anthropological scholars such as Geertz } \\
\text { (1974) and Turner (1997.) Therefore we } \\
\text { have clarified our interpretation. Thanks for } \\
\text { mentioning this. }\end{array}$ \\
\hline $\begin{array}{l}\text { The use of the word 'moment' may seem } \\
\text { like a minor point, but it gives the } \\
\text { impression that something significant is } \\
\text { achieved in a 'split second' in which case } \\
\text { this instance should be discussed in detail. } \\
\text { Also to me, it misrepresents what the paper } \\
\text { achieves in relation to existing research and } \\
\text { takes away from the application of the } \\
\text { concept of 'throwness' which is a significant } \\
\text { contribution. I would like to see this notion } \\
\text { of 'moment' clarified (ie what sort of time } \\
\text { period) and preferably another term } \\
\text { adopted. }\end{array}$ & $\begin{array}{l}\text { We agree that 'moment' is a sensitive term. } \\
\text { We have now further clarified the use of the } \\
\text { term. }\end{array}$ \\
\hline
\end{tabular}




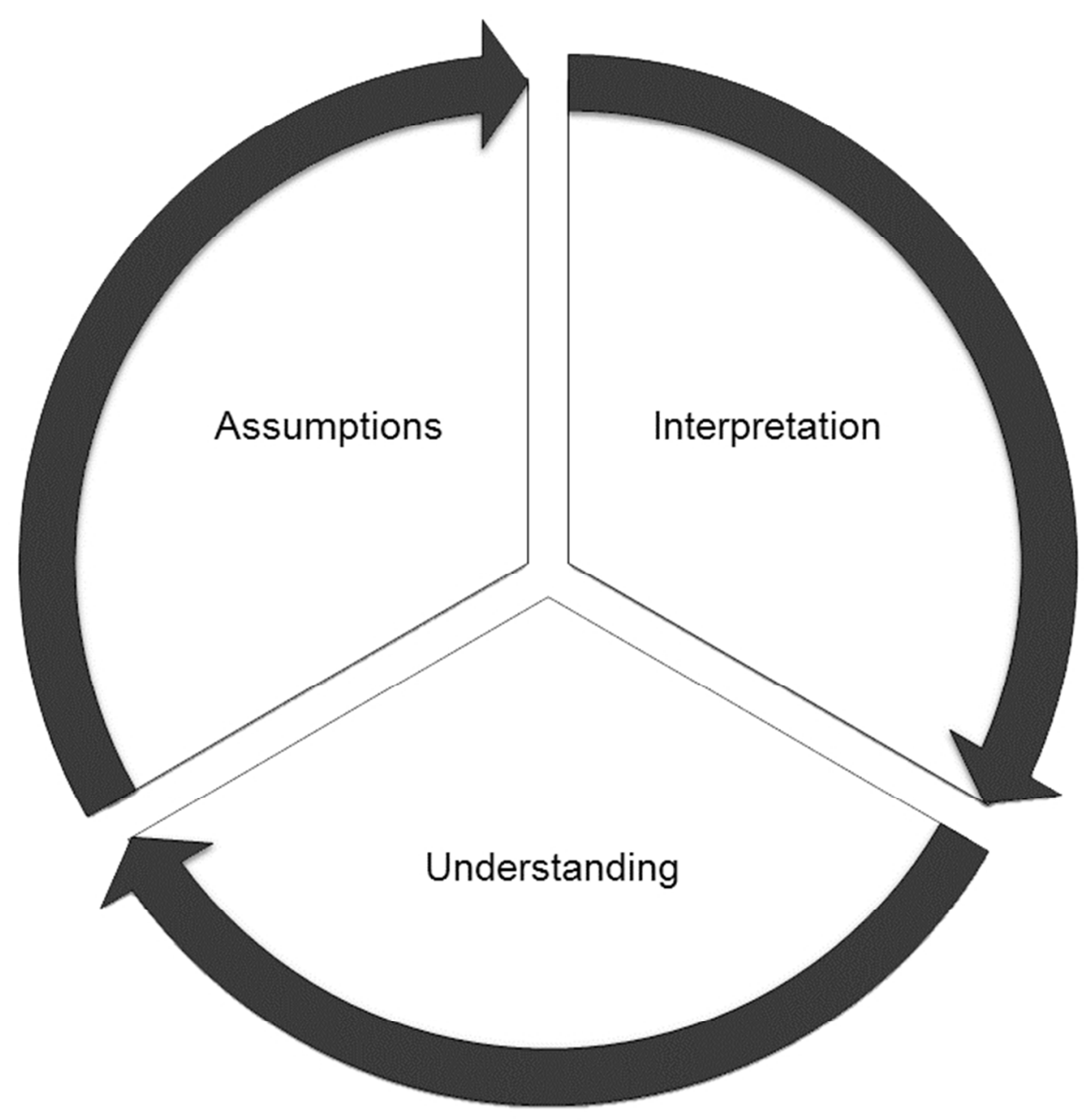

Fig 1. Fore-structure's Circular Relationship Figure 1 


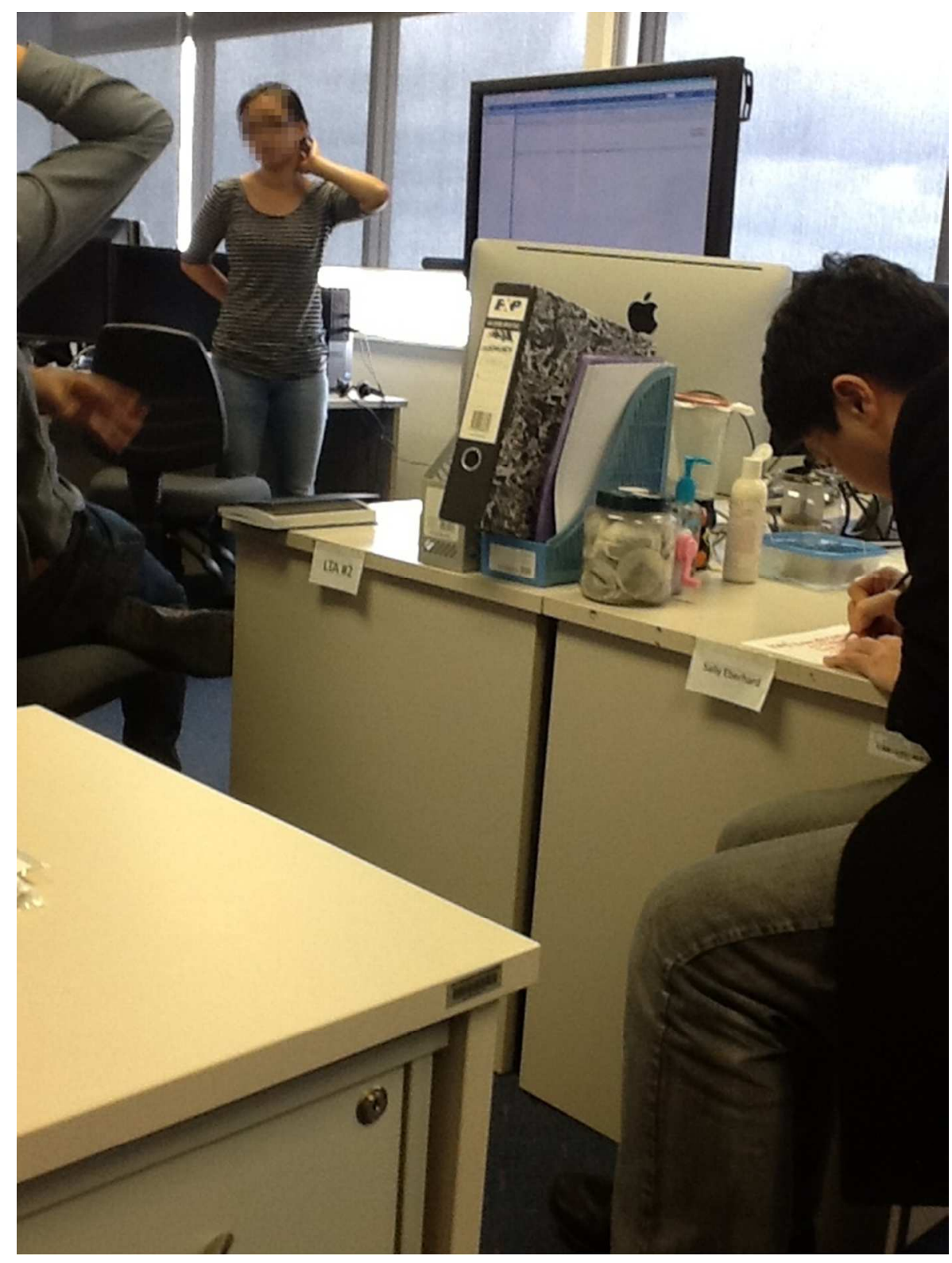

Fig 2. Thrown in the Ethnographic Field

Figure 2

$254 \times 338 \mathrm{~mm}(72 \times 72$ DPI $)$ 